\title{
Vulnerability of National Park Service Beaches to Inundation during a Direct Hurricane Landfall: Cape Lookout National Seashore
}

\author{
Hilary F. Stockdon and David M. Thompson \\ U.S. Geological Survey \\ FISC-St. Petersburg \\ 600 4th Street S.
}

St. Petersburg, FL 33701

\section{Abstract}

Cape Lookout National Seashore, a barrier-island coastal park in North Carolina, is vulnerable to the powerful, sand-moving forces of hurricanes. Waves and storm surge associated with these strong tropical storms are part of a natural process in barrier-island evolution and can cause extensive morphologic changes in coastal parks, leading to road closures and reduced visitor accessibility. The vulnerability of park beaches to inundation, and associated extreme coastal change, during a direct hurricane landfall can be assessed by comparing the elevations of storm-induced mean-water levels (storm surge) to the elevations of the crest of the sand dune that defines the beach system. Maps detailing the inundation potential for Category 1-5 hurricanes can be used by park managers to determine the relative vulnerability of various barrier-island parks and to assess which areas of a particular park are more susceptible to inundation and extreme coastal changes.

\section{Introduction}

Along much of the East Coast of the United States, hurricanes have been responsible for some of the most dramatic changes to our coastal environments - from the creation of large overwash deposits to the opening of new inlets. Strong winds associated with these tropical storms bring large waves and storm surge that force significant changes on fragile barrier islands, where the balance between island stability and rising water levels is maintained by dynamic changes of beach morphology. On developed barrier islands, hurricane-induced coastal change makes local infrastructure more vulnerable to failure. Even in our national coastal parks, where development is strictly managed, hurricanes threaten to destroy infrastructure that keeps the parks operational (roads, communications, park buildings) as well as to alter dramatically the beaches and dunes that provide visitors with the opportunity to observe wildlife and experience the interaction of the land and sea.

The impact of a hurricane on a beach has been shown to be highly variable over both large and small stretches of coast (Stockdon et al., 2003) One section of beach may be largely unaffected by a storm, while an adjacent area experiences extreme coastal change associated with island overwash or breaching. This spatially variable response to storms is partly due to longshore variability of the pre-storm beach morphology combined with variability in the offshore physical forcing (Stockdon et al., 2007a). Using a storm-impact scaling model that compares the relative elevations of barrier-island morphology and storm-induced water levels, the potential vulnerability of a barrier island to extreme coastal change during a hurricane landfall can be defined (Sallenger, 2000).

A complete and comprehensive management plan preparing for a hurricane landfall, as well as plans for post-hurricane recovery, should be based on an assessment of what areas of the coast are most vulnerable. In order to help several of our coastal National Parks prepare for a possible hurricane landfall, the USGS, at the request of the National Park Service (NPS), has prepared an analysis of the vulnerability of Cape Lookout National Seashore (NS) beaches to inundation during a direct landfall. The results can be used to assess what areas of the park are most susceptible to extreme coastal change during a hurricane. These findings can also be compared to those from other NPS coastal parks to determine, in a relative sense, which parks are most at risk during strong tropical storms.

Cape Lookout NS is located in North Carolina between Beaufort Inlet to the southwest and Ocracoke Inlet to the northwest (Fig. 1). The $90 \mathrm{~km}$ of park include the uninhabited barrier islands of Shackleford Banks, South Core Banks, and North Core Banks. The open-ocean beaches of Cape Lookout face the Atlantic Ocean and are susceptible to the forces of approaching hurricanes.

\section{Methods}

\subsection{Storm-impact Scaling Model}

A simple storm-impact scale that compares elevations of the most seaward sand dune to elevations of hurricane-induced water levels can be used to define the likely impact regime for an approaching hurricane (Sallenger, 2000). During a storm, the combined effects of 1) the astronomical tide, 2) storm surge (elevated water levels associated with the large winds and low pressures of a hurricane), and 3) wave runup (the super-elevation of the water surface at the shoreline due to waves, both the time-varying and time-averaged components) move the erosive forces of the storm higher on the beach face than during typical wave conditions. The total elevation of these three parameters defines the maximum water level $\left(R_{\text {high }}\right)$ attained during a storm, while the storm-induced mean-water level $\left(R_{\text {low }}\right)$ can be defined 


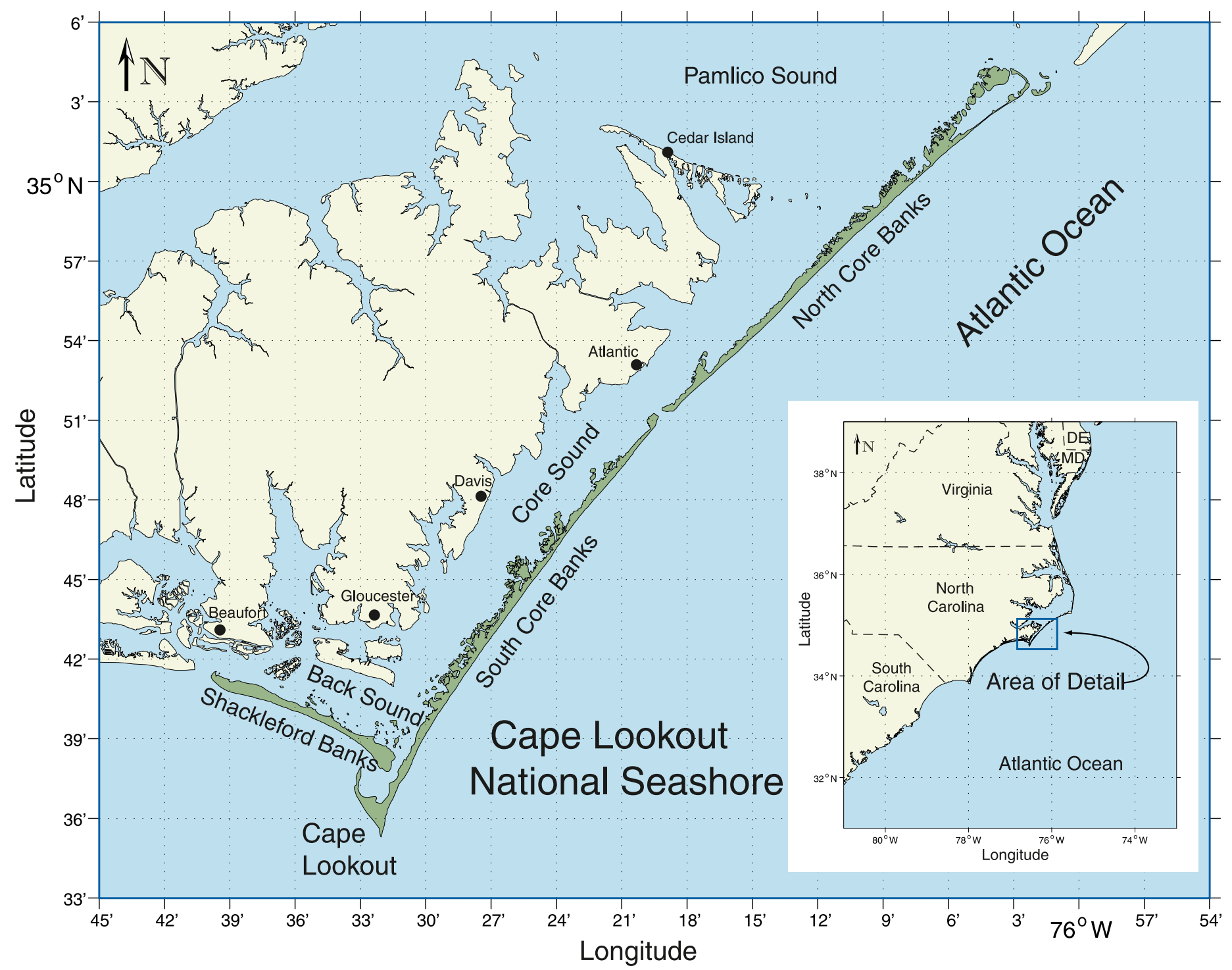

Figure 1. Location map for Cape Lookout National Seashore.

by only storm surge and wave setup. These forces may reach the elevation of the base $\left(D_{\text {low }}\right)$ and crest $\left(D_{\text {high }}\right)$ of the most seaward sand dunes that define the landward limits of the beach system and represent the first-line defense of a barrier island in an approaching storm. Using these parameters, four storm-impact regimes, or thresholds for coastal change, may be defined $-\operatorname{swash}\left(R_{\text {high }}<D_{\text {low }}\right)$, collision $\left(R_{\text {high }}>D_{\text {low }}\right)$, overwash $\left(R_{\text {high }}>\right.$ $\left.D_{\text {high }}\right)$, and inundation $\left(R_{\text {low }}>D_{\text {high }}\right)$-to provide a framework for examining the general types and relative magnitudes of coastal change that are likely to occur during hurricanes (Sallenger, 2000; Stockdon et al., 2007a).

Here we focus on the most extreme of the four impact regimes, inundation, which occurs when the storm-induced mean-water level $\left(R_{\text {low }}\right)$ exceeds the elevation of the crest of the most seaward sand dune $\left(D_{h i g h}\right)$. Within this regime, the beach system (foredune ridge and beach) is completely submerged, and net landward transport of sediment is likely to occur (Sallenger, 2000). Typically, larger magnitudes of shoreline retreat and beach erosion will occur when the beach is inundated due to the transport of sand in both the offshore and onshore directions (Stockdon et al., 2007a).
The predictive accuracy of the scaling model was tested by hindcasting the likely impact of Hurricanes Bonnie and Floyd (Stockdon et al., 2007a) and of Hurricane Ivan (Stockdon et al., 2007b). For Hurricane Ivan, the overall hindcast accuracy of the model in predicting one of the four regime types was $68 \%$. The sensitivity of the model within the inundation regime was $51 \%$ (Stockdon et al., 2007b). Underprediction errors were likely due to profile evolution of the low-lying barriers during the landfall of the Category 4 storm. In order to use this model in a predictive mode to examine the potential for inundation during a future hurricane landfall, accurate estimates of both the dune parameters and the expected hurricane-induced mean-water level are needed.

\subsection{Dune Elevation}

The morphology of the beach and dunes at Cape Lookout NS was mapped based on an airborne lidar topographic survey collected on October 1 and 2, 2005, by the U.S. Army Corps of Engineers (USACE) CHARTS system. GPS-based lidar surveys provide an efficient method for collecting high-reso- 
lution data of subaerial topography with sufficient accuracy (root-mean-square vertical accuracy $=15 \mathrm{~cm}$ ) to resolve the spatial details of sand-dune elevation and position (Sallenger et al., 2003).

The elevation of the foredune crest (or, in the absence of a dune, the beach berm) was extracted every $20 \mathrm{~m}$ along the coast of Cape Lookout NS from cross-shore profiles of lidar topography (Fig. 2). An automatic algorithm was used to select the peak of the most seaward dune within a prescribed beach width (here, $150 \mathrm{~m}$ ). The results were then manually checked to ensure the extraction of a consistent feature defining the landward extent of the beach system (Fig. 3).

\subsection{Storm Surge}

In this analysis, $R_{\text {low }}$ is represented only by the storm surge. Wave setup was not considered because predictions of wave conditions (height and period) for a generic hurricane of each category are not currently available. The predicted elevations of storm surge for Saffir-Simpson Category 1-5 hurricanes were extracted from the NOAA SLOSH (Sea, Lake, and Overland Surges from Hurricanes) model, a real-time forecast model for hurricane-induced water levels for the Gulf and Atlantic Coasts. The numerical model is based on linearized, depth-integrated equations of motion and continuity (Jarvinen and Lawrence, 1985). Storm surge is modeled by simulating the conditions of each-category storm approaching the coast from different angles and at varying speeds. Changes in maximum surge elevations are forced by time-varying wind-stress and pressure-gradient forces that depend on hurricane location, minimum pressure, and size measured from the eyewall out to the location of maximum winds (Jarvinen and Lawrence, 1985). The maximum surge within each grid cell is defined as the Maximum of the Maximum Envelope of Water (MOMs) and represents the worst-case, localized surge that will occur for landfall in a given location, not what would occur along the entire coast for a single storm. The results are location specific, accounting for local water depths, proximity to bays and rivers, etc., and are

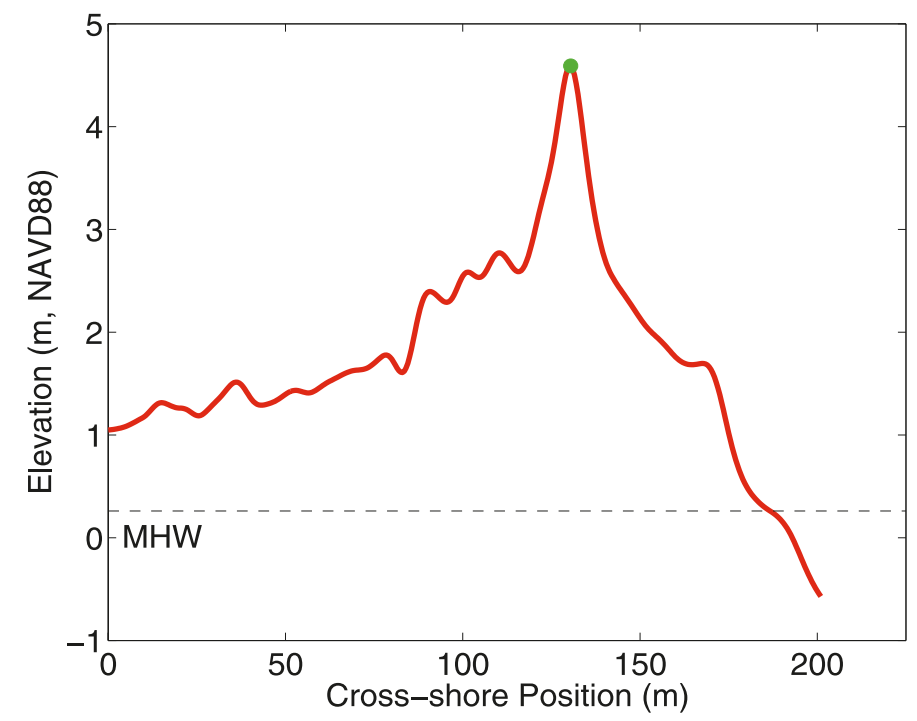

Figure 2. Cross-shore profile of lidar data from Cape Lookout NS showing the location of the most seaward sand dune. The ocean is located to the right. accurate to $\pm 20 \%$ of the calculated value (NOAA, 2007). Errors in the SLOSH model can arise from differences between the parametric wind models, which force SLOSH, and the actual hurricane wind field (Houston et al., 1999) as well as discrepancies between the coarse model grid and the real topography and bathymetry over which the storm may travel.

For Cape Lookout NS, the maximum surge at the shoreline was extracted from the MOMs results for the Pamlico Sound model grid (Fig. 4, left). Maximum, open-coast surge values were extracted at the location of the October 2005 lidar-derived, mean-high-water (MHW; 0.36 m NAVD88 for Shackleford Banks, 0.26 m NAVD88 elsewhere) shoreline position (Fig. 4, right). The Pamlico SLOSH-model grid has an approximate cell size of 2.4 to $2.8 \mathrm{~km}$ along the shoreline of Cape Lookout NS. In locations where grid resolution resulted in anomalously low values because the barrier island was not fully resolved, the most nearshore grid cell representing conditions seaward of the barrier island was chosen.

\section{Inundation Vulnerability}

The potential inundation, $I$, of the beach system was defined every $20 \mathrm{~m}$ along Cape Lookout NS by calculating the difference between the elevations of SLOSH-modeled storm surge $\left(R_{\text {low }}\right)$ for each hurricane category and of lidar-measured dune crests $\left(D_{\text {high }}\right)$ (Fig. 5). Negative values (blues) indicate that water levels are predicted to be lower than the dune crest and that a particular section of beach is not likely to be inundated during the direct landfall of a hurricane. Positive values (reds) signify areas where the beach is more likely to be inundated by storm surge. These estimates assume landfall at mean astronomical tide and do not include the effects of wave setup, which, during strong storms (Category 3 and above), may increase the storm-induced mean-water level by more than $30 \%$ above that due to surge alone. This would increase the beach's vulnerability to inundation. Additionally, the maps represent the vulnerability of the beach system as it was at the time of the October 2005 lidar survey. Major changes to beach morphology, such as those caused by large storms and hurricanes, may change the future vulnerability of this stretch of coast.

For the direct landfall of a Category 1 storm, only $11 \%$ of the Cape Lookout coast is vulnerable to inundation, compared to over $91 \%$ during a Category 5 storm. The eastern half and western $2 \mathrm{~km}$ of Shackleford Banks are more susceptible to inundation: $R_{\text {low }}>D_{\text {high }}$ for these areas for Category 3 and higher storms. Also, areas around inlets are more vulnerable during hurricane landfall. The beaches extending $3.5 \mathrm{~km}$ to the southwest and $1.2 \mathrm{~km}$ to the northeast of New Drum Inlet as well as a 6-km stretch of coast south of Ocracoke Inlet are most vulnerable to inundation during a hurricane landfall: these areas reach or exceed the inundation threshold for Category 2 storms and higher. The longshore variability observed in $I$ is due to spatial variations in the height of the frontal dune. The mean elevation of $D_{\text {high }}$ is $2.81 \mathrm{~m}$ (NAVD88) with substantial longshore variability, standard deviation, $\sigma,=0.95 \mathrm{~m}$ (Fig. 6). Additionally, modeled surge elevations were larger along Shackleford Banks (Fig. 4), making the beach and dunes on this southwest-facing island more vulnerable. The spatially averaged surge for a Category 1 


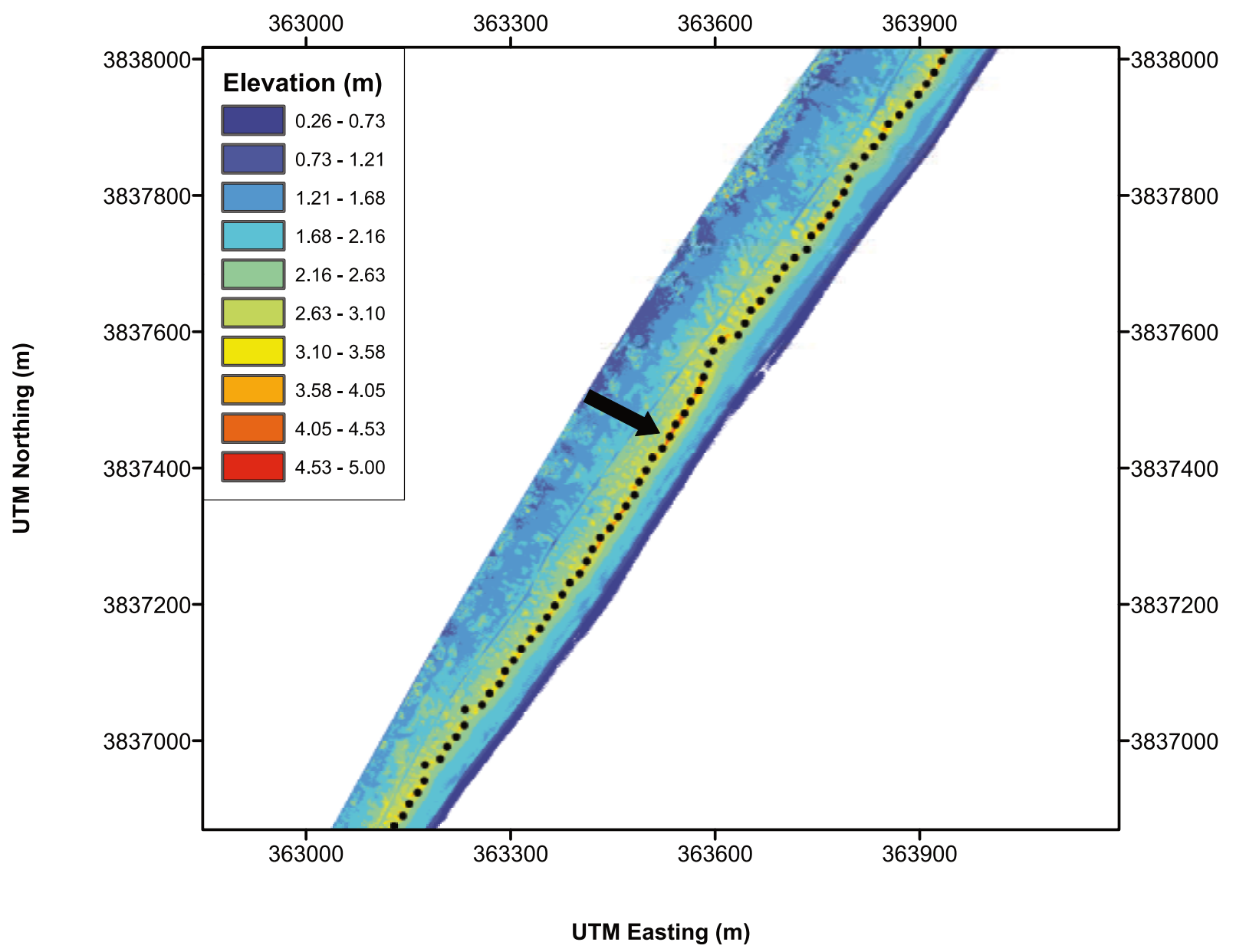

Figure 3. The extracted dune crest for approximately $1.3 \mathrm{~km}$ of the Cape Lookout NS coast, superimposed on the lidar topography. The arrow refers to the location of the profile shown in Figure 2.
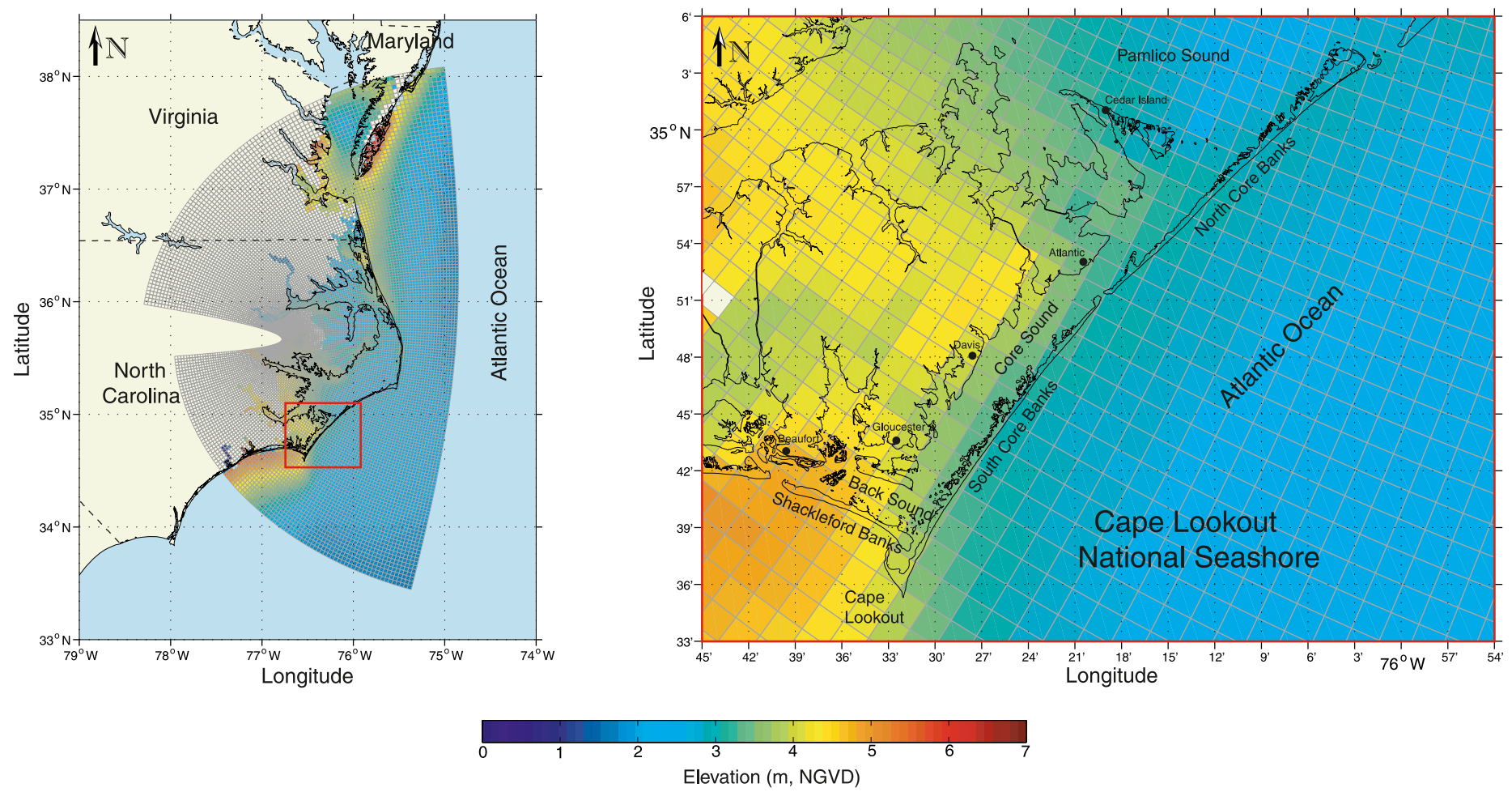

Figure 4. SLOSH-model results for a Category 3 hurricane for the Pamlico Sound model grid (left) shows the variability of modeled surge values along the coast. Maximum, open-coast surge levels for Categories 1-5 hurricanes were extracted from the SLOSH grid along the Atlantic shoreline of Cape Lookout NS (right). 


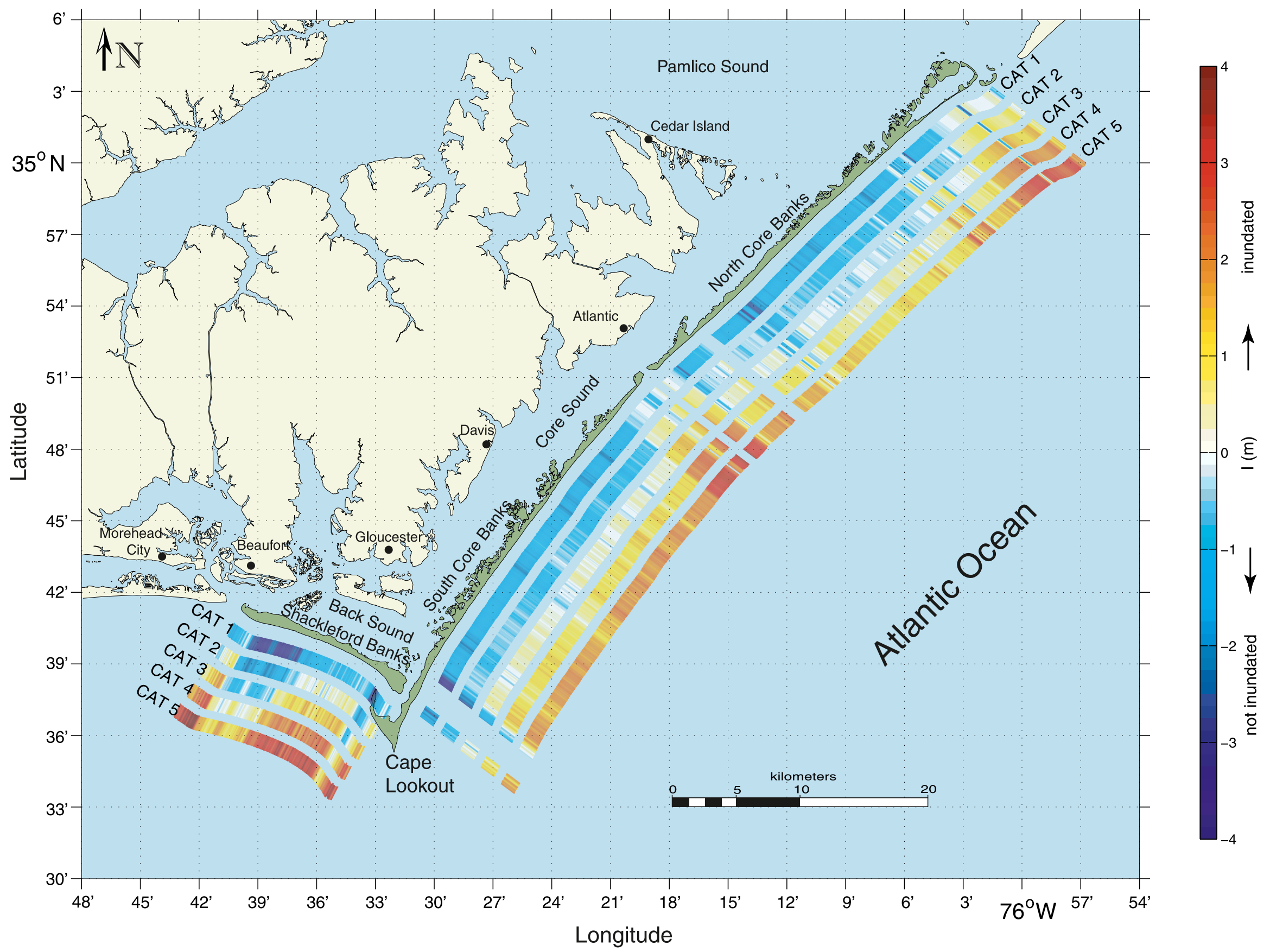

Figure 5. The potential inundation, I, of the beach system at Cape Lookout NS for Categories 1-5 hurricanes is defined as the difference between $R_{\text {low }}$ and $D_{\text {high }}$. A 200-m smoothing window was applied to the data before plotting. Positive values indicate that modeled storm surge exceeds the elevation of the dune crest suggesting that the beach system is more vulnerable to inundation and the associated extreme coastal changes. A larger version of this map can be downloaded from http://coastal.er.usgs.gov/nps-beaches/. 


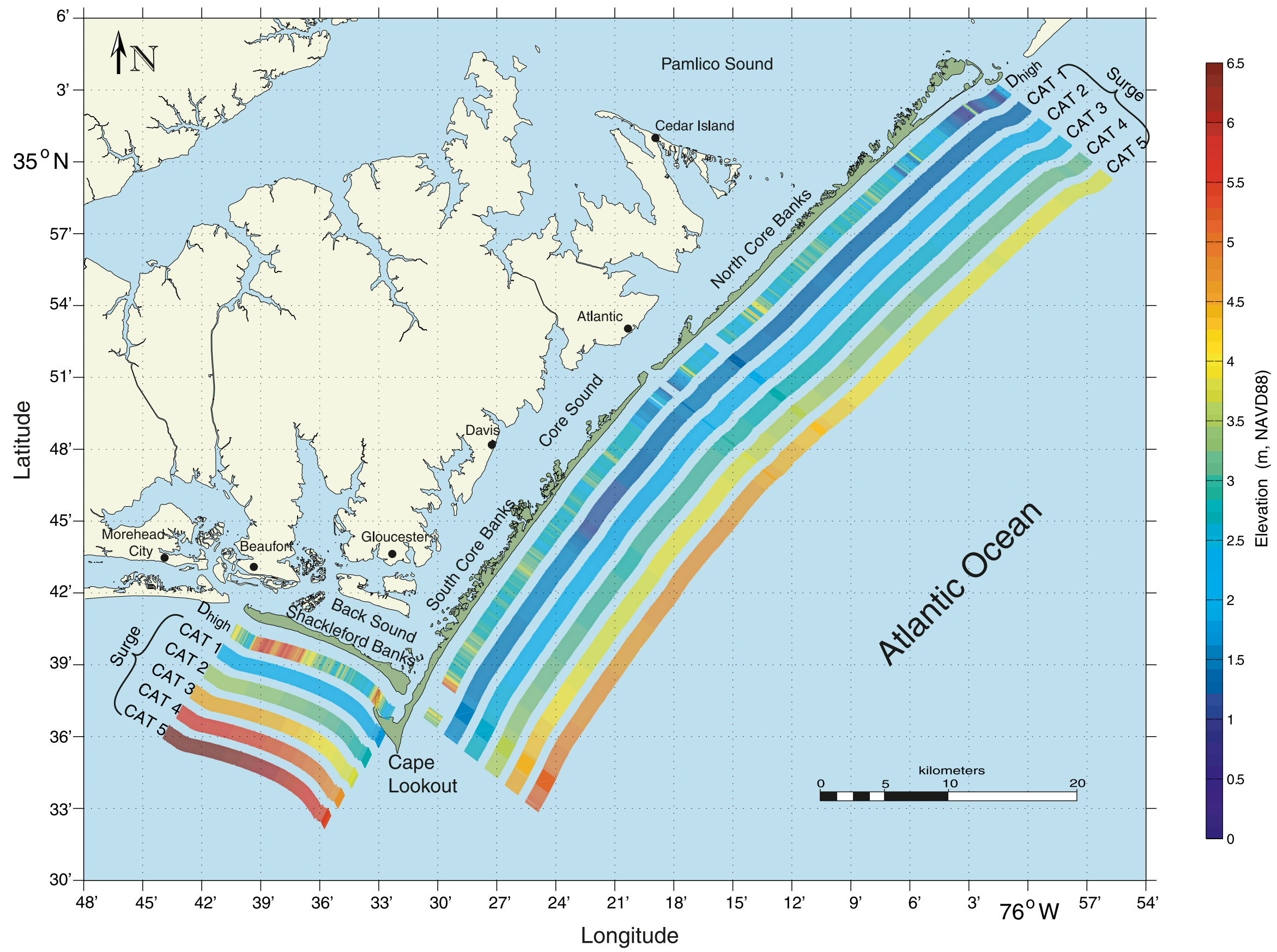

Figure 6. Dune elevations $\left(D_{\text {high }}\right)$ for Cape Lookout NS were measured from a lidar topographic survey collected on 0 ctober 1 and 2, 2005. The surge values $\left(R_{\text {low }}\right)$ for categories 1-5 hurricanes were extracted from the NOAA SLOSH model and represent the open-coast 'maximum of the maximum.' A larger version of this map can be downloaded from http://coastal.er.usgs.gov/nps-beaches/. 
hurricane was $1.51 \mathrm{~m}$, while the average surge for a Category 5 storm was $4.71 \mathrm{~m}$. (Fig. 6)

\section{Rates of Recent Shoreline Change}

Detailed analysis of the historic (150-yr) rates of shoreline change, calculated using the horizontal position of the MHW shoreline from four time periods (mid- to late-1800s, 1920s1940s, 1970s-1980s, and 1997), along Cape Lookout NS show areas of both accretion and erosion (Morton and Miller, 2005). The most erosive areas are Shackleford Banks, the northern end of South Core Banks, and the southern end of North Core Banks, whereas the remaining areas of the park are accreting or relatively stable. Details of the calculations and specific rates of change for both historic and short-term ( 20 yr) periods can be found in Miller et al. (2005).

Rates of recent shoreline change were calculated between the September 1997 shoreline used in the Morton and Miller (2005) analysis and the modern shoreline position as defined using the October 2005 lidar survey that was the basis of the inundation analysis. From each lidar survey, datum-based $(\mathrm{MHW}=$ $0.36 \mathrm{~m}$ and $0.26 \mathrm{~m}$ ) shoreline positions were extracted every 20 $\mathrm{m}$ along the coast using techniques described in Stockdon et al. (2002). Horizontal movement of shoreline, calculated as the difference in position between 2005 and 1997, was highly variable along the $90-\mathrm{km}$ stretch of coast (Fig. 7). The mean change along the coast of the park over the 8 -yr time period was -11.17 $\mathrm{m}$, and the standard deviation was $33.32 \mathrm{~m}$. The largest amount of change was observed adjacent to inlets. Away from inlets, the magnitude of shoreline change ranged from $20.4 \mathrm{~m}$ of accretion near the Cape to $88.0 \mathrm{~m}$ of shoreline retreat southwest of Old Drum Inlet. The mean, short-term change rate over the 8-yr period was $-1.4 \mathrm{~m} / \mathrm{yr}(\sigma=4.17 \mathrm{~m} / \mathrm{yr})$. Detailed rates of change and associated error bars for the length of the park can be found at http://coastal.er.usgs.gov/nps-beaches/.

\section{Discussion}

The inundation vulnerability maps detail the worst-case surge scenario for each location along the coast. Maximum surge typically occurs to the right of landfall under the eyewall and decreases with distance away from the center of the storm. Consequently, the worst case for any given storm is localized and will not occur along the entire coast of Cape Lookout NS. The map shows areas that are most likely to be inundated by storm surge should the hurricane make landfall immediately to the southwest of that particular location.

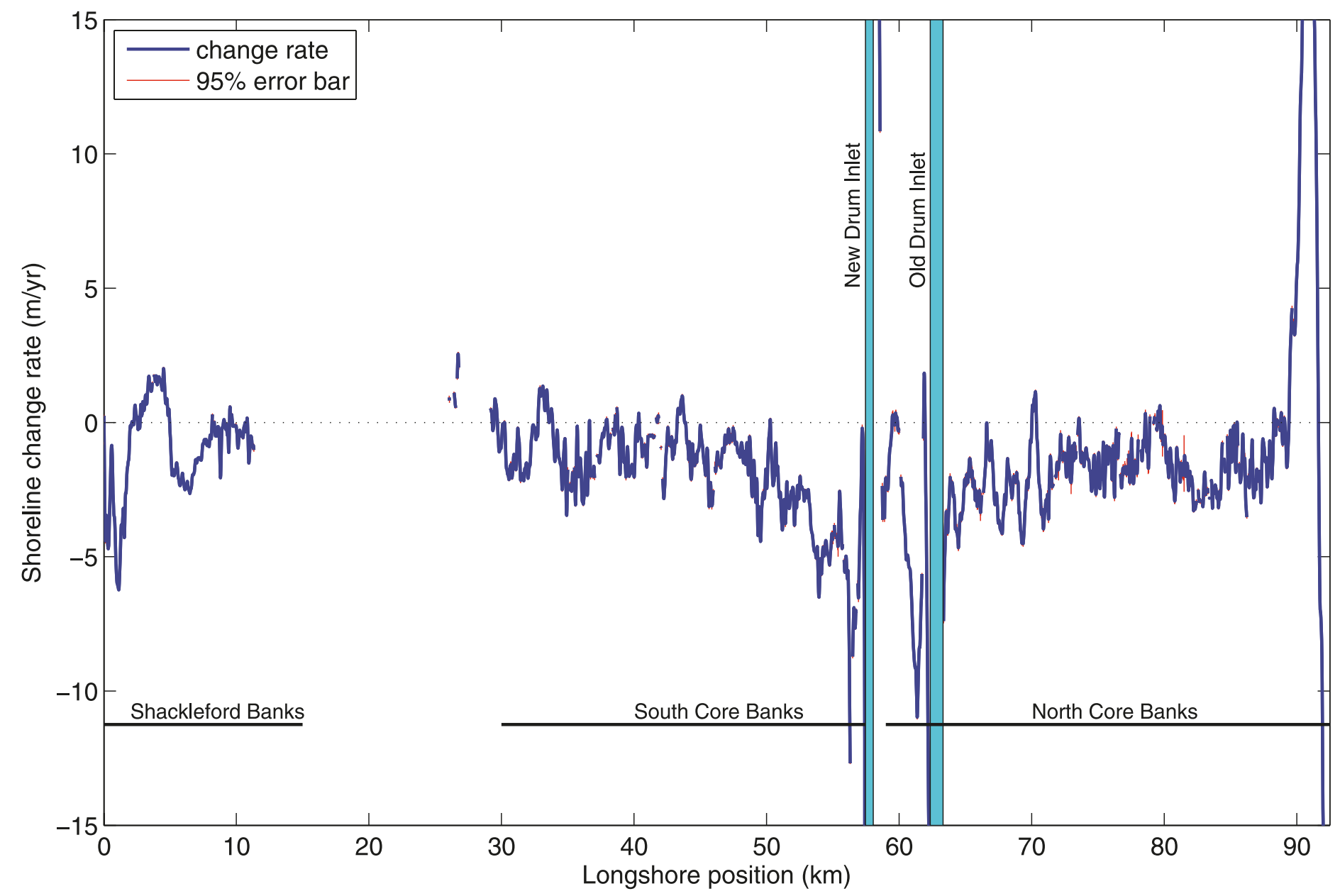

Figure 7. Short-term (8-yr) rates of shoreline change for Cape Lookout NS. Data were smoothed with a 100-m window. Negative values indicate erosion. The mean rate is $-1.41 \mathrm{~m} / \mathrm{yr}$. The gap in the data between 15 and $30 \mathrm{~km}$ in the longshore is due to poor lidar coverage around the shoals of Cape Lookout. 
If the beach system is inundated, the dune will be overtopped by storm surge. Strong waves and currents may transport large amounts of sand landward across the island. These types of changes have been shown to be more long-lasting because sand removed from the beach face does not typically return in the years following storm landfall (Stockdon et al., 2007a). Under some conditions, the currents will create new or expose relict inlets, such as those on Core Banks and Hatteras Island during the 2003 landfall of Hurricane Isabel.

\section{Acknowledgments}

We thank Rebecca Beavers and Mark Borrelli (NPS) for their assistance in the development of this project. The lidar data were collected by Jeff Lillycrop (USACE) and his CHARTS team. We also thank Betsy Boynton, Kara Doran, Kristy Guy, Peter Howd, Abby Sallenger, Jolene Shirley, and Charlene Sullivan (USGS) for their contributions to this study. John Fry, Tony Curtis, and Linda York (NPS) provided early reviews of the map products. This work was funded by National Park Service, Natural Resource Program Center.

\section{References}

Houston, S.H., Shaffer, W.A., Powell, M.D., and Chen, J., 1999, Comparisons of HRD and SLOSH surface wind fields in hurricanes: Implications for storm surge modeling: Weather and Forecasting, v. 14, p. 671-686.

Jarvinen, B.R., and Lawrence, M.B., 1985, An evaluation of the SLOSH storm surge model: Bulletin of the American Meteorological Society, v. 66, p. 1408-1411.

Miller, T.L., Morton, R.A., and Sallenger, A.H., 2005, National Assessment of Shoreline Change: A GIS Compilation of Vector Shorelines and Associated Change Data for the U.S. Southeast Atlantic Coast: U.S. Geological Survey, Open-File Report 2005-1326, St. Petersburg, FL.

Morton, R.A. and Miller, T.L., 2005, National Assessment of Shoreline Change: Part 2, Historical Shoreline Changes and Associated Coastal Land Loss Along the U.S. Southeast Atlantic Coast: U.S. Geological Survey, Open-File Report 2005-1401, St. Petersburg, FL, 40 pp.

NOAA, National Hurricane Center, 2007, Hurricane Preparedness: SLOSH model: http://www.nhc.noaa.gov/HAW2/ english/surge/slosh.shtml, last accessed August 24, 2007.

Sallenger, A.H., 2000, Storm impact scale for barrier islands: Journal of Coastal Research, v. 16, p. 890-895.

Sallenger, A.H., Krabill, W., Swift, R., Brock, J., List, J., Hansen, M., Holman, R.A., Manizade, S., Sontag, J., Meredith, A., Morgan, K., and Stockdon, H., 2003, Evaluation of airborne scanning lidar for coastal change applications: Journal of Coastal Research, v. 19, p. 125-133.

\section{For more information:}

For the USGS:

Hilary F. Stockdon

David M. Thompson

U.S. Geological Survey

Florida Integrated Science Center-St. Petersburg $6004^{\text {th }}$ Street S.

St. Petersburg, FL 33701

Tel: (727) 803-8747

Email:

For the NPS-GRD:

Mark Borrelli

National Park Service

Natural Resource Program Center

Geologic Resources Division (GRD)

P.O. Box 25287

Denver, CO 80225-0287

Tel: (303) 969-2171

Stockdon, H.F., Sallenger, A.H., Holman, R.A., and Howd, P.A., 2007a, A simple model for the spatially-variable coastal response to hurricanes: Marine Geology, v. 238, p. 1-20.

Stockdon, H.F., Sallenger, A.H., Howd, P.A., and Holman, R.A., 2003, Longshore variability of the coastal response to Hurricanes Bonnie and Floyd: Proceedings, International Conference on Coastal Sediments 2003, Clearwater Beach, FL, CD-ROM.

Stockdon, H.F., Sallenger, A.H., List, J.H., and Holman, R.A., 2002, Estimation of shoreline position and change from airborne scanning lidar data: Journal of Coastal Research, v. 18 , p. 502-513.

Stockdon, H.F., Thompson, D.M., and Sallenger, A.H., 2007b, Hindcasting potential hurricane impacts on rapidly changing barrier islands: Proceedings, 6th International Conference on Coastal Sediments, New Orleans, p. 976-985. 